\title{
【令和元年度廃棄物資源循環学会セミナー報告】
}

\section{SDGs スタンダードな生活衛生・資源循環インフラ}

\author{
一焼却・エネルギー回収・資源回収・最終処分の普及一
}

日鉄エンジニアリング株) 小野 義 広

\section{1. 開催概要}

2019 年 11 月 14 日 (木) 田町駅そばの専売ホールに おいてセミナー「SDGs スタンダードな生活衛生・資源 循環インフラ一焼却・エネルギー回収・資源回収・最 終処分の普及一」が開催された。秩父薰雅企画運営委 員長から開会挨拶と趣旨説明の後, はじめに環境省環境 再生・資源循環局廃棄物適正処理推進課 名倉良雄氏か らの基調講演, 続いて第 1 部を東京都環境科学研究所 飯野成憲氏，第 2 部を国連環境計画 本多俊一氏の座長 のもと, 各登壇者から講演, パネルディスカッションが 行われ, 活発な意見交換が行われた。長田守弘副会長の 閉会挨拶後に意見交換会も開催され各分野の方々による 交流が行われた。以下, 今回のセミナーの概要について 紹介する。

\section{2. 開催内容}

\section{基調講演}

(1)「SDGs 達成のためにごみ処理技術が果たす役割と わが国が目指す展開」

環境省 名倉良雄 氏

SDGs を改めて考えると いうより環境省としては普 段行ってきた業務が SDGs そのものである。廃棄物処 理は歴史的にみて, 適正処 理・衛生的処理が基本とな る。そして次のステップと して資源循環があり，さら

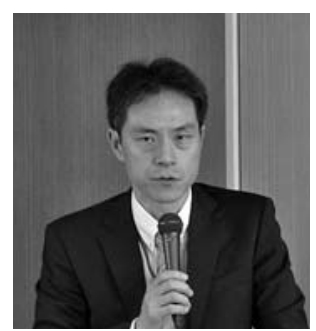

に発展して地域循環共生圈の形成につながってきた。現 在はこれらの技術を海外へ展開するような段階になって いる。海洋プラスチック（以下, プラ）については, わ が国の経験, 知見, 技術を国際的に発信, 展開しつつ 「新たな污染を生み出さない世界」を目指した実効的な 対策に取り組むこととしている。また廃プラ対策では中 国の受入停止の問題でプラスチックの処理が逼迫し, 環
[プログラム]

$13: 20 \sim 13: 25$ 開会の挨拶

(一社) 廃棄物資源循環学会企画運営委員長

\section{基調講演}

秩父 薰雅

13:25〜 $13: 45$ SDGs 達成のためにごみ処理技術が果たす 役割とわが国が目指す展開 環境省 環境再生・資源循環局 廃棄物適正処理推進課 名倉 良雄

第 1 部 SDGs の目標・ターゲットと焼却・資源/エネルギー 回収・最終処分

座長 東京都環境科学研究所 飯野 成憲

$13: 45 \sim 14: 05$ 多極世界が目指すSDGs：自立的社会イン フラに必要な技術とシステム

(国研)国立環境研究所 資源循環 ·

廃棄物研究センター 河井 紘輔

$14: 05 \sim 14: 25$ 自然に還る最善の最終処分のために焼却技 術に期待すること

福岡大学環境保全センター 柳瀬 龍二

$14: 25 \sim 14: 45$ 焼却残椬の環境安全管理と有効利用のあり方 (国研)国立環境研究所 資源循環 . 廃棄物研究センター 肴倉 宏史

$14: 45 \sim 15: 05$ 燃焼, エネルギー回収, 排ガス処理システ ムのあり方

(一社) 日本環境衛生施設工業会 増田 孝弘

15:05 15:25 水分・塩分・金属成分を含む都市ごみ燃料 そのバリエーションにどう対応するか 大阪工業大学 渡辺 信久

第 2 部 普及にふさわしい SDGs スタンダードな技術のあり かたを探る

$15: 35 \sim 15: 55$ SDGs に打ける廃棄物資源循環技術の在り方 国連環境計画国際環境技術センター 本多 俊一

$15: 55$ 16:50 パネルディスカッション コーディネーター：本多 俊一

$16: 50 \sim 16: 55$ 閉会の挨拶 パネリスト：上記講演者

(一社) 廃棄物資源循環学会副会長 長田 守弘

境省としても一般廃棄物処理施設での廃プラ受入の検討 を依頼したが, これらは一時的なものであり，本質的に は国内での資源循環体制を構築していく必要がある。 
第 1 部 SDGs の目標・ターゲットと焼却・資源/エネ ルギー回収・最終処分

(2)「多極世界が目指す SDGs : 自律的社会インフラに 必要な技術とシステム」

(国研国立環境研究所 河井紘輔 氏 現在「SDG 指標 11.6.1」 としてゴール・ターゲット への達成指標が新たに定め られようとしている。廃棄 物においては「収集率」や 「適正処理率」が用いられ ることになる。収集率につ

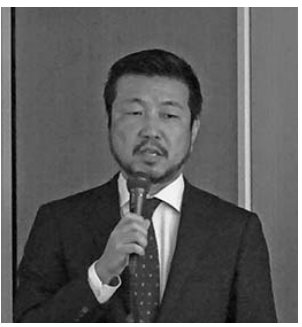
いてベトナムでのデータで

は人々の月収と収集率に相関がある。温室効果ガス削減 の観点では，処理方式による効果の違いが検討されてい る。結果的には, メタン発酵であれ焼却であれ，どの方 式を選ぶかよりも，まず生ごみを埋立て処分せずに中間 処理することが重要である。発展途上国での都市ごみ処 理では, 自治体が直営でごみ処理を行っている例はほと んどなく，地元業者に丸投げでモニタリングもされてい ないケースが多い。肥料化や焼却等の検討が行われつつ あるが, 地方政府がこれらの設備の導入に伴い何が必要 となるか, どういう問題が起こるのか想定できていない。 これらを解決することが最も大事である。

(3)「自然に還る最善の最終処分のために焼却技術に期 待すること」

日本の最終処分場では排 ガス処理に用いる消石灰や， 反応物に含まれる $\mathrm{Cl}$ の影 響により, (1) Cl 流出 (塩 害), (2)Caスケールによる 設備トラブル，(3)キレート や高反応消石灰由来の有機 物による COD 上昇等が起 福岡大学 柳瀬龍二 氏 きている。排ガス中 $\mathrm{HCl}$ の大気污染防止法の基準 $430 \mathrm{ppm}$ に対して $50 \mathrm{ppm}$ 以下のような自主基準の設定がこのよ うな結果につながっており, 最終処分場で起こる問題や コストを考えてどの程度を目指すべきなのか考えるべき である。また以前から確認されていた事象として，焼却 灰の強熱減量が下がりすぎることで高 $\mathrm{pH}$ 化や有機物活 性の阻害等も起こっている。強熱減量の $5 \%$ を $2 \%$ に 下げたところで減容化率はほとんど変わらないことを考 え，強熱減量を $5 \%$ 前後までとするような焼却を考え てよいのではないか。
(4)「焼却残さの環境安全管理と有効利用のあり方」 (国研)国立環境研究所 看倉宏史 氏 焼却施設や溶融施設では 加熱に伴う元素の濃縮や精 製が起きている。炉のさま ざまな箇所から扊や残椬が 排出されるが, その発生場 所により元素含有量が異 なっている。焼却残椬の資 源化, 処分方法には溶融,

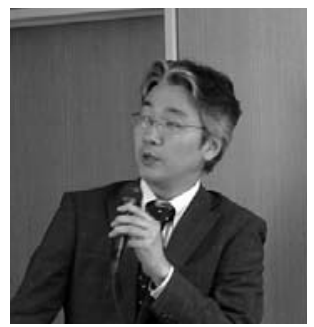
焼成，セメント原料化，改質・土木資材化，埋立処分が あるが，留意点として共通していることは，金属の事前 除去である。ヨーロッパでは焼却主灰から金属類を分 別・分級して貴金属原料として売却することが商業的に 行われており，日本でも取り組みが始まっている。また， ヨーロッパでは焼却主灰の直接資源化も行われている。 日本で同様のことを行う場合には安全性の確保とともに その基準等が必要となってくる。

(5)「燃焼, エネルギー回収, 排ガス処理システムのあ り方」

(一社) 日本環境衛生施設工業会 増田孝弘 氏 日本の焼却技術は, $4,000 \mathrm{~kJ} / \mathrm{kg}$ を切るような ごみの完全然焼を目指して スタートし，その後ごみ質 の変化やごみカロリーの上 昇, 公害問題やダイオキシ ン問題等の社会的要求に対 応しながら発展してきた。 アジア地域ではごみカロリーの低い地域が多いが日本の 経験を活かし幅広いごみ質に対応可能である。排ガス処 理システムについては日本では厳しい排ガス基準に適応 できるさまざまなオプションをもっているが，コスト， エネルギー回収等を考えシンプルなものを基本とすべき と考える。アジア地区への技術提供の際には建設だけで なく, 維持・運営管理まで含めた LCC 的な観点で計画 することが大事であることを伝えていきたい。 
（6)「水分・塩分・金属成分を含む都市ごみ燃料：その バリエーションにどう対応するか」

大阪工業大学 渡辺信久 氏

発電効率を高くできない のはごみ中 $\mathrm{Cl}$ による腐食 があるからであり, $\mathrm{Cl}$ に よる腐食はプラスチック類 からよりも㕑芥類からのも のがより激しい。途上国の 都市ごみは水分・塩分が多

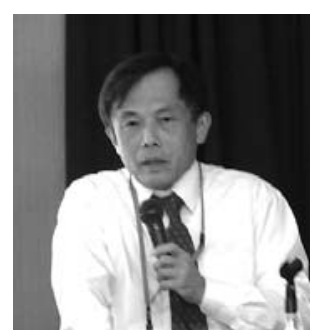
く発電には不利である。そ こでごみ処理の廃熱の有効な利用先としてNAS 電池 (ナトリウム・イオン電池) への熱供給を提案したい。 NAS 電池は日本のオリジナル技術であり電力密度が大 きく大型化が容易であるが, $300{ }^{\circ} \mathrm{C}$ 程度に温度を保つ必 要がある。ソーラーパネルで発電し, NAS 電池で平滑 化して供給する。このNAS 電池の熱源に都市ごみ焼却 の廃熱を利用するというスキームが有効と考える。 SDGs 的に「誰も取り残さないために」を考えると大規 模広域インフラ整備の次に都市域以外や後発途上国が対 象となってくるが, 小型分散型のニーズが高まってくる。 小型炉は日本の得意分野であり, このスキームはその有 効な手段である。

\section{第 2 部 普及にふさわしい SDGs スタンダードな技術 のあり方を探る}

(7)「SDGsにおける廃棄物資源循環技術の在り方」

\section{国連環境計画 本多俊一 氏}

SDGs $の 1 丁$ 目 1 番地は 「貧困をなくすこと」であ る。アフリカの多くの国で は「ごみ」はほとんどが オープンダンピングされて いる。そこには多くのウェ イストピッカーが1日 100 円以下の賃金でプラや金属

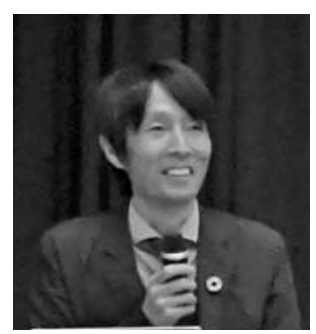
を素手で集めている。これらの人々を救わなければなら ない。全世界的にみると一般廃棄物の半分はオープンダ ンピングされている。現状の予想では焼却・リサイク ル・管理された埋め立ては増えていくものの, 廃弃物発 生量の増加もあり 2050 年でもオープンダンピングの全 体量は変わらない。このオープンダンピングをどう減ら していくか考えなければならない。

日本でできることは何だろうか。一つは今の技術を高 度化し先端化することである。そして, 先端技術をシン プル化して途上国でも使えるものとすることと考える。
(8) パネルディスカッション

$$
\text { コーディネーター 本多俊一氏 }
$$

パネラー 全講演者

本多氏からの「資源循環インフラ分野に执いて SDGs 的視点で日本がやるべきことは何だろうか？」という テーマに対して, 各家庭に扔ける分別排出というンフト (渡辺氏), 適正処理・公衆衛生 (増田氏), 管理型最終 処分場への移行 (柳瀬氏), 廃棄物処理システムの構築 （河井氏）等があげられた。また，日本のやり方をその ままもちこんでも上手くいかない(名倉氏), 日本が経 験した問題を繰り返さないようなアドバイスが必要（看 倉氏)，ありがた迷惑にならないようニーズの見極めが 必要（渡辺氏），現地で成り立っているスキームを壊す ようなことは避けるべき(河井氏), 中国が力をつけて きた中で支援とかいっていられないのではないか（名倉 氏), 国連は一緒に答えを出していくというスタンスで あり，まずは現地の技術を育てて技術力がついてくると 先進国の技術が必要となる（本多氏）等の意見があった。 また「日本が世界に進出して課題を解決できる手段が あるか?」というテーマに対して, 生ごみ処理は世界的 にも問題になるはずで将来の日本の課題解決にも繋がる のではないか (河井氏), まずはオープンダンピングで の作業環境改善, ごみを均してウェイストピッカーが拾 いやすくするだけでも違う (柳瀬氏), 現地のシステム を尊重しょく勉強することが大事である（渡辺氏）など の提言があった。

最後に本多氏から「本日の内容をまとめる必要はない と思う。各講演者の話を聞いて皆さんがいろいろな考え を知り，それぞれで何が必要か考えていただいたと思う。 それこそがこのセミナーの目的だと考える」とのコメン トで締め括られた。

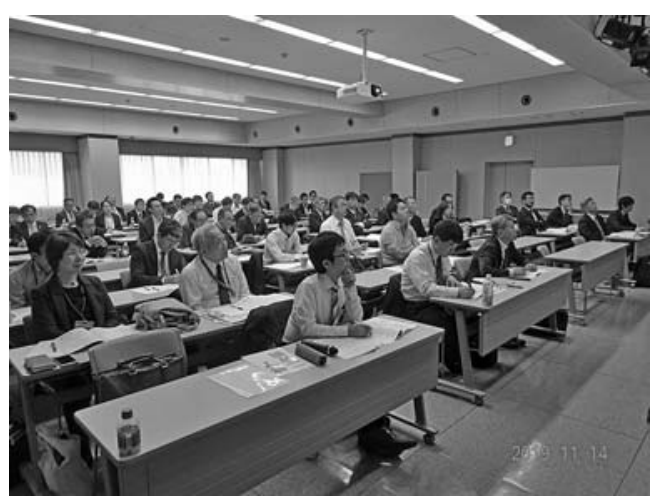

図 1 会場の様子 